\title{
On the determinants of trade openness in low- and lower-middle-income countries in Africa: how important is economic growth?
}

\author{
Dennis Boahene Osei ${ }^{1^{*}} \mathbb{D}$, Yakubu Awudu Sare ${ }^{2}$ and Muazu Ibrahim²
}

\begin{abstract}
The existing literature highlights the determinants of trade openness with disregard to the income classifications of countries in examining whether the determinants differ given their income levels. This study, therefore, re-examines the drivers of trade openness in Africa relying on panel data with special focus on the role of economic growth. More specifically, we perform a comparative analysis of the factors influencing trade openness for low-income and lowermiddle-income countries using the system generalized method of moments. Our findings suggest that, while economic growth robustly enhances openness in low-income countries, in the case of lower-middle-income countries, the impact is not robust and largely negative suggesting that higher growth is associated with less openness. We also find that, economic growth-openness nexus for the lower-income countries exhibits non-linearities and inverted U-shaped relationship in particular. Thus, while increases in real GDP per capita enhance openness, beyond an estimated threshold point, any increases in economic growth dampen openness. We discuss key implications for policy.
\end{abstract}

Keywords: Trade openness, Economic growth, Low-income countries, Lower-middle-income countries, GMM, Africa

\section{Introduction}

The level of countries' openness to international trade has been a critical preoccupation of many countries in Africa. Indeed, more opened economies allow for enhanced international trade and integration with international markets. Yanikkaya [20] documents that the degree to which countries are open to international trade has recently gained scholarly interest because several empirical studies have concluded that trade openness accelerates economic growth. However, empirical literature on the determinants of trade openness has not been rigorous and remains sparse.

At the empirical front, a study by Alesina and Wacziarg [1] examined the link between trade openness, country size and government. They argued that the nexus between government size and trade openness is mediated by country size. The least square regression estimates

\footnotetext{
*Correspondence: denniskwakuboahene@gmail.com

${ }^{1}$ Wits Business School, University of the Witwatersrand, 2 St David's Place,

Parktown, Johannesburg, South Africa

Full list of author information is available at the end of the article
}

showed that country size is negatively related to government size as well as to trade openness. Further result indicates a positive relationship between government size and trade openness mediated by country size effect, especially for the government consumption part of government spending. This finding confirmed the assertion of the authors that the relationship between government size and trade openness is mediated by country size.

Jansen and Nordås [12] uses ordinary least squares to analyze the impact of institutions on trade openness in both developing and developed economies while controlling for domestic trade policy and infrastructure. The authors uncover that all institutional variables (rule of law, government effectiveness and control of corruption) are positively related to trade openness. Further evidence indicates that while domestic infrastructure has a significant positive impact on trade openness, no significant evidence was found between domestic tariffs and trade openness nexus. In addition, interactive effect of domestic tariffs and institution on trade openness was analyzed and the study finds a significant negative relationship between the interactive term and trade openness. This 
result suggests that the larger the marginal impact of a reduction in tariffs on trade openness, the better the institutional quality.

Moreover, Guttmann and Richards [8] analyzed the determinants of trade openness in Australia. The authors found population and economic location to potential trade partners as the most crucial determinants of trade openness. More specifically, their finding further suggested that countries which are relatively more remote and have larger population trade less. Apart from this, trade policy and economic development were also identified as important determinants of trade openness. However, total area of countries was highlighted as least determinants of trade openness as little evidence was found in support of total area-trade openness nexus.

By extending the openness model of Guttmann and Richards [8] to include additional regressors such as mining sector as a proportion of gross domestic product (GDP), agriculture as a proportion of GDP and regional multiplicative dummies of African continent, Mbogela [15] studied determinants of trade openness in Africa. The results based on fixed-effect panel estimation technique indicated that population, GDP per capita and economic location are important factors explaining the level of trade openness among the African countries. For the main variables of interest, the study highlighted a negative relationship between agricultural proportion of GDP and trade openness, and argued that the relationship holds because agricultural products are not dominant in the trade ratios anymore. Again, mining as a percentage of GDP was found to be a distinctive determinant of trade openness as the study indicated a positive relationship between mining as a proportion of GDP and trade openness in Africa. The study concluded by singling out Tanzania to make a comparative analysis. Results indicated that population, income levels and economic location are the most important factors that explain Tanzania's trade openness. By implication, the author suggested trade openness ratio for Tanzania could improve if it could have lower population that would mean an increased in GDP per capita assuming it is constant with the change in the population.

Kim et al. [13] examined relationships between financial development and trade openness using unbalanced panel data for 87 countries spanning from 1960 to 2005 . Findings from their study indicate that while short-run relationship between financial development and trade openness is substitute, long-run relationship was complementary. Nevertheless, after splitting the sample into Organization for Economic Co-operation and Development (OECD) and non-OECD countries, this finding is observed only in non-OECD countries supporting the view that financial development has significant real effects for developing countries relative to the developed ones. Besides, result from their threshold analysis suggests a non-linear long-run relationship where trade openness decreases with financial development.

Also, Jafari et al. [11] in a study on the determinants of trade flows among D8 countries observes crucial factors that affect the volume of export flows among member countries. Notably, among these factors affecting export flows are trading partners' gross domestic product, exchange rate, population of exporter country, border and distance.

More recently, a study by Tahir et al. [19] focused on South Asian Association for Regional Cooperation (SAARC) member countries to analyze macroeconomic determinants of trade openness using data spanning from 1971 to 2011. Their study relied heavily on fixed-effect panel estimation technique to conclude that macroeconomic determinants matter significantly for higher trade openness. More specifically, it was found that while physical capital, human capital and GDP per capita positively influence trade openness, labor force and exchange rate negatively affect trade openness. The study emphasized on prudent steps by policy makers in SAARC to liberalize trade regimes by efficient macroeconomic management.

Furthermore, Sare et al. [18] examined the determinants of international trade measured by openness and exports in Africa relying on data for 46 countries over the period 1980-2015. Results from their system generalized method of moments suggest that financial development proxied by private credit does not promote openness, while domestic credit positively affects international market integration. Further evidence shows a U-shaped relationship between private credit and trade. While inflation and gross fixed capital formation robustly improve openness, savings, population and real GDP per capita are far from being robust determinants. Indeed, from the foregoing, the existing literature highlights the determinants of trade openness without disaggregating the sample according to the income classifications in examining whether the determinants differ given the income level of the countries. Thus, these studies have assumed homogenous income status for all the countries under consideration. Therefore, this study aims at re-examining the determinants of trade openness in Africa relying on panel data. More specifically, we perform a comparative analysis of the determinants of trade openness between lowincome and lower-middle-income countries in Africa using the system generalized method of moments.

The study contributes significantly to the literature. First, through a comparative analysis for the low- and lower-middle-income countries, the study unearths that the determinants of trade openness differ given the income status of countries. Second, we dwell on 
Table 1 Descriptive statistics

\begin{tabular}{|c|c|c|c|c|c|c|}
\hline \multirow[t]{2}{*}{ Variables } & \multicolumn{3}{|l|}{ LICs } & \multicolumn{3}{|l|}{ LMICs } \\
\hline & Mean & Std. dev. & CV & Mean & Std. dev. & CV \\
\hline Trade openness & 57.52 & 27.77 & 0.48 & 77.83 & 36.43 & 0.47 \\
\hline Private credit & 12.31 & 8.91 & 0.72 & 22.80 & 17.27 & 0.76 \\
\hline Domestic credit & 26.94 & 80.18 & 2.98 & 36.33 & 27.48 & 0.76 \\
\hline Real GDP per capita & 509.42 & 236.41 & 0.46 & 1724.60 & 871.21 & 0.51 \\
\hline Inflation & 98.36 & 1288.94 & 13.10 & 33.05 & 222.91 & 6.74 \\
\hline Gross fixed capital formation & 17.33 & 7.93 & 0.46 & 20.74 & 9.26 & 0.45 \\
\hline Population & 50.92 & 2.06 & 0.04 & 53.67 & 4.60 & 0.09 \\
\hline Savings & 3.83 & 14.98 & 3.91 & 16.78 & 13.70 & 0.82 \\
\hline
\end{tabular}

Std. dev. and CV, respectively, denote standard deviation and coefficient to variation. LICs and LMICs represent low-income countries and lower-middle-income countries, respectively

the importance of economic growth by establishing the threshold effect of growth on openness. To the best of our knowledge, existing studies have not been rigorous in investigating the factors influencing countries' integration with the international markets. Our findings suggest that, while economic growth measured by real GDP per capita robustly enhances openness in low-income countries, in the case of lower-middle-income countries, the impact is not robust and largely negative suggesting that higher growth is associated with less openness. We also find that, economic growth-openness nexus for the lower-income countries exhibits non-linearities and inverted U-shaped relationship in particular. While financial development matters more for lower-income countries, the impact of finance on openness for lowermiddle income is benign. Domestic savings, inflation and gross fixed capital formation are robust determinants of trade openness for lower-income countries. However, for lower-middle-income countries, only capital formation significantly spurs integration with international markets.

The rest of the paper is organized as follows: the next section presents the methodology. It is followed by the discussion of our findings. The last section concludes the study with some implication for policy.

\section{Methods}

\section{Data and preliminary findings}

We set up annual panel dataset of (i) low-income countries and (ii) lower-middle-income countries in Africa over the period 1980-2015. The choice of these countries is based on data availability over a relatively longer period. ${ }^{1}$ Trade openness is proxied by the sum of imports and exports as a percentage of GDP. Following Ibrahim and Alagidede [9] and Sare et al. [18], this is taken to measure the level of countries' integration with the international markets. We also use two measures of financial

\footnotetext{
${ }^{1}$ We show the list of countries in Appendix.
}

sector development which have been extensively used in recent literature $[10,18]$ : private and domestic credits to GDP ratio. First, the private credit refers to financial resources provided to the private sector by financial corporations, such as through loans, purchases of nonequity securities and trade credits. However, domestic credit provided by the financial sector includes all credit to various sectors on a gross basis, with the exception of credit to the central government. Therefore, the private and domestic credits to GDP are more directly linked to investment. With regard to economic growth, we rely on countries' level real GDP per capita income measured in constant 2010 U.S. dollars, while population ages 15-64 (\% of total) is taken as the active labor. Inflation is the annual percentage change in the consumer price index and used to proxy influence of countries' macroeconomic (in)stability on trade openness. We also rely on gross fixed capital formation as a percentage of GDP to proxy investment rates. Gross domestic saving is computed as gross national income less total consumption, plus net transfers. Data on all these variables were sourced from the World Development Indicators (WDI) of the World Bank. Table 1 presents the descriptive statistics of our variables.

From the Table, we observe a mean trade openness of $57.52 \%$ and $77.83 \%$ for the low-income and lower-middleincome countries, respectively. Thus, given the average values of openness, our evidence suggests that lowermiddle-income countries (LMICs) are more opened to trade relative to the low-income countries (LICs). To allow inter-level volatility comparison, we compute the coefficient of variation as the ratio of standard deviation to mean where higher (lower) values of CV imply higher (lower) volatility. Thus, given the CV of trade openness, although the LMICs are relatively more integrated with the international market, the volatility in openness is homogenous. With regard to financial development, our 


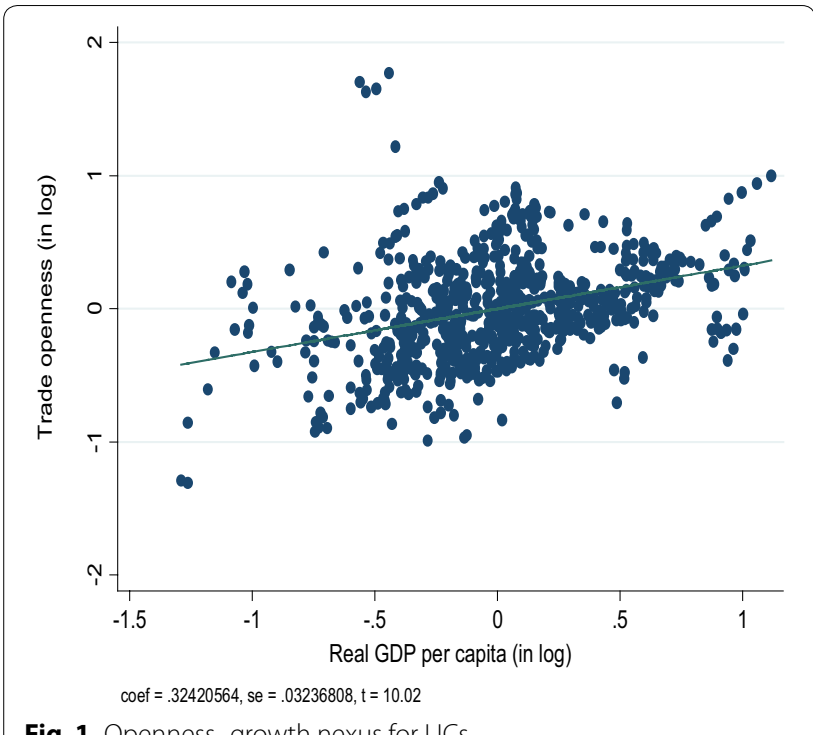

Fig. 1 Openness-growth nexus for LICS

findings suggest that, financial markets in the LMICs are well developed compared to LICs. This holds given their higher values of private and domestic credits as a percentage of GDP. Interestingly, while there is no variation in the level of volatility between private and domestic credits among LMICs, in the case of LICs, domestic credit is exceedingly volatile. Consistent with their classification, real GDP per capita is higher among the LMICs and measures at least 3.4 times higher than that of the LICs. The level of volatility between these income groups does not vary significantly although real GDP per capita appears more volatile. While both the LMICs and LICs are inflationary given the high values of inflation, the latter income group's level of macroeconomic instability is huge and weights about thrice larger with wide variations. The means of gross fixed capital formation, population and domestic savings are all higher among the LMICs relative to LICs. This notwithstanding, while domestic saving is more volatile in LICs, population in LMICs are comparatively higher with homogenous gross fixed capital formation in both income groups. Given the aim of this study, we plot in Figs. 1 and 2 openness-economic growth nexus to provide a cursory view of the link.

We observe a positive and statistically significant effect of real GDP per capita on trade openness for both groups of countries suggesting that higher income growth is associated with improved higher openness. Given the coefficients, the openness enhancing effect of economic growth is huge for the LMICs relative to the LICs. However, the link between countries' level of openness and economic growth is complex and far from being determined by the simple relationship involving only overall level of economic growth. Thus, a more nuanced and

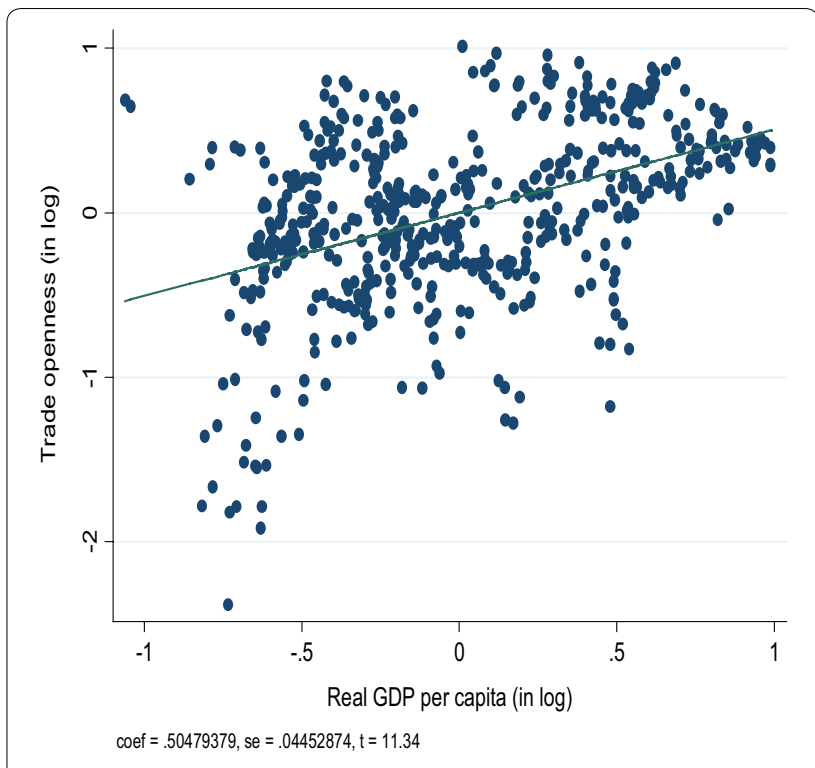

Fig. 2 Openness-growth nexus for LMICS

in-depth analysis is needed. We do this by first discussing our empirical strategy in the next section.

\section{Empirical strategy}

To the extent that the overarching aim of this study is to determine the factors influencing countries' level of integration with the international markets, we set a model where trade openness depends on its one-period lag, economic growth and other control variables namely financial development, inflation, savings, gross fixed capital formation and labor. Specifically, we specify the following equation:

$$
\mathrm{TRA}_{i t}=\gamma_{o} \mathrm{TRA}_{i t-1}+\gamma_{1} \mathrm{ECO}_{i t}+\gamma_{2} \mathrm{CON}_{i t}+\mu_{i t},
$$

where TRA $\mathrm{T}_{i t-1}$ is the one-period lag of trade openness which is used to examine the convergence effect of openness in Africa; $\mathrm{ECO}_{i t}$ and $\mathrm{CON}_{i t}$ represent economic growth and vector of control variables, respectively; $\mu_{i t}$ is the error term, while $i$ and $t$ represent country and time indices, respectively.

Indeed, from Eq. (1), economic growth enhances trade openness if $\gamma_{1}>0$ and significant at conventional levels. In other words, increases (decreases) in economic growth enhance (inhibits) countries' integration with the international markets. Beyond the linear impact of economic growth, we examine whether trade openness-economic growth nexus exhibits nonlinearities.

We do this by including a quadratic square term of economic growth in the openness equation in (1) above, thus producing Eq. (2): 
$\mathrm{TRA}_{i t}=\gamma_{o} \mathrm{TRA}_{i t-1}+\gamma_{1} \mathrm{ECO}_{i t}+\rho \mathrm{ECO}_{i t}^{2}+\gamma_{2} \mathrm{CON}_{i t}+\varepsilon_{i t}$, $\varepsilon_{i t}=\vartheta_{i}+v_{t}+\mu_{i t}$,

where $\vartheta_{i}$ is unobserved country-specific fixed effects; $v_{t}$ is the time effects, while $\varepsilon_{i t}$ is the idiosyncratic error term. From Eq. (2), $\rho$ measures the quadratic term. We determine the nature of the nonlinearities by relying on the sign of $\gamma_{1}$ and $\rho$. However, to investigate for the threshold point, we differentiate Eq. (2) with respect to economic growth and setting the result to zero.

It is imperative to note that, introducing the lagged term of trade openness may cause a potential endogeneity since TRA $\mathrm{A}_{i t-1}$ depends on $\varepsilon_{i t-1}$ which is a function of the country-specific effect $\left(\vartheta_{i}\right)$. We, therefore, estimate the equations relying on the generalized method of moments (GMM) proposed by Arellano and Bond [2] which removes $\vartheta_{i}$ or any related time-invariant countryspecific variable present in the data. Baltagi et al. [4] argue that, in addition to controlling for endogeneity resulting from the correlation between $\beta_{i}$ and the righthand-side regressors, taking the first difference in the use of GMM renders all the variables stationary. To estimate the drivers of trade openness, we employ the system GMM which combines both a regression in its first difference and in levels [3, 5]. In addition, we use 4-year data averaging (1980-1983; 1984-1987; 1988-1991; .......; 2012-2015) to avoid biased estimates in addition to abstracting from business cycle components that may be present in the data. Doing this produces nine non-overlapping time periods where $T=9$.

Indeed, the reliability of the GMM results depends on the instruments. We assess this using the Sargan test of over-identifying restrictions which examines whether our set of instruments, as a group, are exogenous. To the extent that too many instruments potentially over fit our instrumented variables, for $\mathrm{TRA}_{i t-1}$, we use as instruments the first difference lagged one period for the equations in levels. However, for the equations in first difference, we use the first lagged value. With regard to the other regressors which are taken to be endogenous, we use the second lagged value as instruments. Based on this, we adopt the two-step system GMM. In addition, we also test for the absence of second-order serial correlation of the residuals.

\section{Findings and discussions}

This section presents empirical findings on the determinants of trade openness. More specifically, we estimate five models in sequence, by introducing some set control variables, selected based on theory and earlier empirical studies, to highlight the robustness of the drivers of trade openness in LICs and LMICs in Africa.
Besides, the study posits that countries are more likely to open to trade upon attainment of a certain level of income and hence, using economic growth as a threshold variable, we analyzed the threshold effect of trade openness-growth nexus. The results from the system GMM are shown in Tables 2 and 3, respectively. With the post estimation tests to check for the models adequacy, the $p$-values of the Wald Chi-square statistic suggest that at $1 \%$ the regressors in each model are jointly significant. The Sargan's test of over-identification restriction supports validity of the instruments as we fail to reject the null hypotheses of overall exogeneity of the instruments. The $p$-values for [AR (2)] indicate no evidence of second-order autocorrelation. To sum up, the reliability estimates indicate well-specified models.

Evidence from Tables 2 and 3 indicate that the coefficient of lagged trade openness is positive and statistically significant irrespective of the model specification. This suggests that current trade openness depends on the past values of trade openness confirming divergence in openness. Thus, countries with improved initial level of openness continue to be more open to trade relative to countries with low initial openness. More specifically, opening up to trade in the past positively influences current trade openness. This holds for both the LICs and LMICs in Africa. With regard to the effect of economic growth proxied by real GDP per capita, our result suggests a significant positive effect of economic growth on trade openness for LICs compared to an unanticipated negative effect for LMICs. Thus, while higher economic growth increases the level of openness to trade in LMICs, in the case of LICs, it is associated with lower openness.

For instance, from Table 2, a unit-percentage increase in real GDP per capita magnifies trade openness by approximately $0.036 \%$ (column 1 ) and $0.035 \%$ (column 2 ). The implication is that higher levels of economic growth are associated with higher trade openness for LMICs. The result remains robust at $1 \%$ level of significance when we control for financial development (column 1 and 2) and population (column 3). This finding is akin with economic theory and also confirms the empirical study by Yanikkaya [20]. For the LICs, we found that at $1 \%$ level of significance, a unit increase in real GDP per capita reduces trade openness by approximately $0.013 \%$ (see Table 3, column 1) and $0.011 \%$ (column 2). This is consistent with Mbogela's [15] finding, implying that higher levels of economic growth reduce openness to international trade. Overall, economic growth is a distinctive driver of trade openness although the growth effect on trade openness changes for both low-income and lowermiddle-income countries in Africa, respectively. 
Table 2 Determinants of trade openness in LICs

\begin{tabular}{|c|c|c|c|c|c|}
\hline & 1 & 2 & 3 & 4 & 5 \\
\hline Lagged trade openness & $\begin{array}{l}0.4925^{* * *} \\
(0.0442) \\
{[0.000]}\end{array}$ & $\begin{array}{l}0.4729^{* * *} \\
(0.0547) \\
{[0.000]}\end{array}$ & $\begin{array}{l}0.4702^{* * *} \\
(0.0546) \\
{[0.000]}\end{array}$ & $\begin{array}{l}0.4772^{* * *} \\
(0.0532) \\
{[0.000]}\end{array}$ & $\begin{array}{l}0.4133^{* * *} \\
(0.0709) \\
{[0.000]}\end{array}$ \\
\hline Real GDP per capita & $\begin{array}{l}0.0360^{* * *} \\
(0.010) \\
{[0.000]}\end{array}$ & $\begin{array}{l}0.0346^{* * *} \\
(0.0115) \\
{[0.003]}\end{array}$ & $\begin{array}{l}0.0465^{* * *} \\
(0.0128) \\
{[0.000]}\end{array}$ & $\begin{array}{l}0.0493^{* * *} \\
(0.0126) \\
{[0.000]}\end{array}$ & $\begin{array}{l}0.1092^{* * *} \\
(0.0263) \\
{[0.000]}\end{array}$ \\
\hline Private credit & $\begin{array}{l}-0.2270 \\
(0.1992) \\
{[0.256]}\end{array}$ & - & $\begin{array}{l}-0.7745^{*} \\
(0.4147) \\
{[0.062]}\end{array}$ & $\begin{array}{l}-0.6169^{*} \\
(0.3592) \\
{[0.086]}\end{array}$ & $\begin{array}{l}-0.7906^{* *} \\
(0.3223) \\
{[0.014]}\end{array}$ \\
\hline Domestic credit & - & $\begin{array}{l}0.1644^{* * *} \\
(0.0512) \\
{[0.001]}\end{array}$ & $\begin{array}{l}0.3233^{* *} \\
(0.1389) \\
{[0.020]}\end{array}$ & $\begin{array}{l}0.2862^{* *} \\
(0.1296) \\
{[0.027]}\end{array}$ & $\begin{array}{l}0.2102^{* *} \\
(0.0960) \\
{[0.029]}\end{array}$ \\
\hline Inflation & $\begin{array}{l}0.0011^{* * *} \\
(0.0001) \\
{[0.000]}\end{array}$ & $\begin{array}{l}0.0011^{* * *} \\
(0.0001) \\
{[0.000]}\end{array}$ & $\begin{array}{l}0.0010^{* * *} \\
(0.0002) \\
{[0.000]}\end{array}$ & $\begin{array}{l}0.0010^{* * *} \\
(0.00019) \\
{[0.000]}\end{array}$ & $\begin{array}{l}0.00131^{* * *} \\
(0.00021) \\
{[0.000]}\end{array}$ \\
\hline Gross fixed capital formation & $\begin{array}{l}0.8876^{* * *} \\
(0.2190) \\
{[0.000]}\end{array}$ & $\begin{array}{l}0.7749^{* * *} \\
(0.2480) \\
{[0.002]}\end{array}$ & $\begin{array}{l}1.2686^{* * *} \\
(0.4069) \\
{[0.002]}\end{array}$ & $\begin{array}{l}1.0331^{* * *} \\
(0.2504) \\
{[0.000]}\end{array}$ & $\begin{array}{l}0.8770^{* *} \\
(0.3822) \\
{[0.022]}\end{array}$ \\
\hline Population & $\begin{array}{l}-0.0789 \\
(3.8352) \\
{[0.984]}\end{array}$ & $\begin{array}{l}-0.1633 \\
(3.124) \\
{[0.958]}\end{array}$ & $\begin{array}{l}3.1714 \\
(3.7525) \\
{[0.398]}\end{array}$ & - & - \\
\hline Domestic savings & $\begin{array}{l}-0.7186^{* * *} \\
(0.0212) \\
{[0.000]}\end{array}$ & $\begin{array}{l}-0.6295^{* * *} \\
(0.0757) \\
{[0.000]}\end{array}$ & $\begin{array}{l}-0.7363^{* * *} \\
(0.1333) \\
{[0.000]}\end{array}$ & $\begin{array}{l}-0.7162^{* * *} \\
(0.1265) \\
{[0.000]}\end{array}$ & $\begin{array}{l}-0.7580^{* * *} \\
(0.1305) \\
{[0.000]}\end{array}$ \\
\hline Real GDP per capita squared & - & - & - & - & $\begin{array}{l}-0.00004^{* * *} \\
(0.00001) \\
{[0.001]}\end{array}$ \\
\hline Threshold & & & & & $\$ 1365^{\mathrm{a}}$ \\
\hline \multicolumn{6}{|l|}{ Diagnostics } \\
\hline Country and time effects & Yes & Yes & Yes & Yes & Yes \\
\hline $\begin{array}{l}\text { Wald } \chi^{2} \\
{[p \text {-value }]}\end{array}$ & $\begin{array}{l}5990.12 \\
{[0.000]}\end{array}$ & $\begin{array}{l}4227.13 \\
{[0.000]}\end{array}$ & $\begin{array}{l}2153.86 \\
{[0.0000]}\end{array}$ & $\begin{array}{l}2153.86 \\
{[0.000]}\end{array}$ & $\begin{array}{l}521.91 \\
{[0.000]}\end{array}$ \\
\hline $\begin{array}{l}\text { Sargan test } \\
\text { [p-value] }\end{array}$ & $\begin{array}{l}11.353 \\
{[0.243]}\end{array}$ & $\begin{array}{l}13.453 \\
{[0.264]}\end{array}$ & $\begin{array}{l}16.422 \\
{[0.201]}\end{array}$ & $\begin{array}{l}18.623 \\
{[0.231]}\end{array}$ & $\begin{array}{l}14.453 \\
{[0.621]}\end{array}$ \\
\hline $\begin{array}{l}\operatorname{AR}(2) \\
{[p \text {-value }]}\end{array}$ & $\begin{array}{l}-2.754 \\
{[0.322]}\end{array}$ & $\begin{array}{l}-3.243 \\
{[0.234]}\end{array}$ & $\begin{array}{l}-3.123 \\
{[0.266]}\end{array}$ & $\begin{array}{l}-2.627 \\
{[0.311]}\end{array}$ & $\begin{array}{l}-3.001 \\
{[0.261]}\end{array}$ \\
\hline No. of groups & 22 & 22 & 22 & 22 & 22 \\
\hline
\end{tabular}

a $\frac{\partial \text { (Trade openness })}{\left.\partial \text { (Real GDP per capita }_{i t}\right)}=\beta_{1}+2 \beta_{2}$ Real GDP per capita $_{i t}=0 \Rightarrow$ Real GDP per capita $_{i t}=-\frac{\beta_{1}}{2 \beta_{2}} \Rightarrow-\frac{0.1092}{2(-0.00004)}=\$ 1365$

$*$, ** and ${ }^{* * *}$ denote $10 \%, 5 \%$, and $1 \%$ significance levels, respectively

Using private credit and domestic credit as proxies for financial development, we found that the coefficient of financial development alternates signs based on the measure of financial development. For instance, Table 2 shows that private credit negatively and significantly affects trade openness in LICs in Africa suggesting that $1 \%$ increase in private credit reduces trade openness by $0.77 \%$. This implies that financial development hinders trade openness. This finding support Kletzer and Bardhan's [14] theoretical evidence and perhaps reflects the weaker financial institutions associated with financial fragility in Africa, leading to lower demand for external finance which hinders international trade and its openness. By contrast, results from LMIC in Africa shown in Table 4 indicate that the coefficient of private credit is positive albeit not statistically significant suggesting that financial development does not matter in enhancing trade openness. Again, using domestic credit as indicator for financial development, our finding reveals that while there is a significant positive effect of domestic credit on trade openness in low-income countries in Africa, the reverse holds for LMICs in Africa although the coefficients are not statistically significant. In particular, from Table 3, our result shows that trade openness increases by $0.32 \%$ (column 3 ) following a $1 \%$ rise in domestic credit. This clearly highlights that financial 
Table 3 Determinants of trade openness in LMICs

\begin{tabular}{|c|c|c|c|c|c|}
\hline & 1 & 2 & 3 & 4 & 5 \\
\hline Lagged trade openness & $\begin{array}{l}0.8431^{* * *} \\
(0.1799) \\
{[0.000]}\end{array}$ & $\begin{array}{l}0.7458^{* * *} \\
(0.2338) \\
{[0.001]}\end{array}$ & $\begin{array}{l}0.5826^{* * *} \\
(0.2454) \\
{[0.018]}\end{array}$ & $\begin{array}{l}0.7840^{* * *} \\
(0.1737) \\
{[0.000]}\end{array}$ & $\begin{array}{l}0.6409 * * * \\
(0.2609) \\
{[0.014]}\end{array}$ \\
\hline Real GDP per capita & $\begin{array}{l}-0.0127^{* *} \\
(0.0057) \\
{[0.027]}\end{array}$ & $\begin{array}{l}-0.0112^{*} \\
(0.0059) \\
{[0.057]}\end{array}$ & $\begin{array}{l}-0.0189^{* * *} \\
(0.0068) \\
{[0.006]}\end{array}$ & $\begin{array}{l}-0.0110 \\
(0.0084) \\
{[0.193]}\end{array}$ & $\begin{array}{l}-0.0507^{*} \\
(0.0275) \\
{[0.065]}\end{array}$ \\
\hline Private credit & $\begin{array}{l}0.5550 \\
(0.4744) \\
{[0.242]}\end{array}$ & - & $\begin{array}{l}1.3474^{* *} \\
(0.6650) \\
{[0.043]}\end{array}$ & $\begin{array}{l}0.4124 \\
(0.9808) \\
{[0.674]}\end{array}$ & $\begin{array}{l}0.6934 \\
(0.4614) \\
{[0.133]}\end{array}$ \\
\hline Domestic credit & - & $\begin{array}{l}-0.1251 \\
(0.3913) \\
{[0.749]}\end{array}$ & $\begin{array}{l}-0.8986^{*} \\
(0.5365) \\
{[0.094]}\end{array}$ & $\begin{array}{l}-0.1150 \\
(0.6571) \\
{[0.861]}\end{array}$ & $\begin{array}{l}-0.6371 \\
(0.4716) \\
{[0.177]}\end{array}$ \\
\hline Inflation & $\begin{array}{l}0.0243^{*} \\
(0.0144) \\
{[0.091]}\end{array}$ & $\begin{array}{l}0.0219 \\
(0.0158) \\
{[0.165]}\end{array}$ & $\begin{array}{l}0.0071 \\
(0.0173) \\
{[0.681]}\end{array}$ & $\begin{array}{l}0.2433 \\
(0.2331) \\
{[0.297]}\end{array}$ & $\begin{array}{l}0.0290^{* *} \\
(0.0124) \\
{[0.019]}\end{array}$ \\
\hline Gross fixed capital formation & $\begin{array}{l}1.3684^{* *} \\
(0.5625) \\
{[0.015]}\end{array}$ & $\begin{array}{l}0.9023^{*} \\
(0.4839) \\
{[0.062]}\end{array}$ & $\begin{array}{l}1.3677^{* *} \\
(0.5589) \\
{[0.014]}\end{array}$ & $\begin{array}{l}1.2539^{* * *} \\
(0.4790) \\
{[0.009]}\end{array}$ & $\begin{array}{l}1.1557^{* *} \\
(0.5464) \\
{[0.034]}\end{array}$ \\
\hline Population & $\begin{array}{l}-1.346 \\
(4.1337) \\
{[0.745]}\end{array}$ & $\begin{array}{l}2.1210 \\
(3.6910) \\
{[0.565]}\end{array}$ & $\begin{array}{l}-1.5990 \\
(4.0560) \\
{[0.693]}\end{array}$ & - & - \\
\hline Domestic savings & $\begin{array}{l}0.7819^{* *} \\
(0.4108) \\
{[0.057]}\end{array}$ & $\begin{array}{l}0.4839 \\
(0.4776) \\
{[0.311]}\end{array}$ & $\begin{array}{l}0.4044 \\
(0.4796) \\
{[0.399]}\end{array}$ & $\begin{array}{l}0.5935 \\
(0.5045) \\
{[0.239]}\end{array}$ & $\begin{array}{l}0.4772 \\
(0.5177) \\
{[0.357]}\end{array}$ \\
\hline Real GDP per capita squared & - & - & - & - & $\begin{array}{l}7.90 \mathrm{e}-06 \\
(4.81 \mathrm{e}-06) \\
{[0.101]}\end{array}$ \\
\hline \multicolumn{6}{|l|}{ Diagnostics } \\
\hline Country and time effects & Yes & Yes & Yes & Yes & Yes \\
\hline $\begin{array}{l}\text { Wald } \chi^{2} \\
{[p \text {-value }]}\end{array}$ & $\begin{array}{l}115.11 \\
{[0.000]}\end{array}$ & $\begin{array}{l}103.75 \\
{[0.000]}\end{array}$ & $\begin{array}{l}130.31 \\
{[0.000]}\end{array}$ & $\begin{array}{l}49.26 \\
{[0.000]}\end{array}$ & $\begin{array}{l}314.73 \\
{[0.000]}\end{array}$ \\
\hline $\begin{array}{l}\text { Sargan test } \\
{[p \text {-value }]}\end{array}$ & $\begin{array}{l}17.423 \\
{[0.534]}\end{array}$ & $\begin{array}{l}19.145 \\
{[0.498]}\end{array}$ & $\begin{array}{l}18.523 \\
{[0.423]}\end{array}$ & $\begin{array}{l}19.222 \\
{[0.614]}\end{array}$ & $\begin{array}{l}21.234 \\
{[0.576]}\end{array}$ \\
\hline $\begin{array}{l}\operatorname{AR}(2) \\
{[p \text {-value }]}\end{array}$ & $\begin{array}{l}-4.533 \\
{[0.257]}\end{array}$ & $\begin{array}{l}-4.092 \\
{[0.297]}\end{array}$ & $\begin{array}{l}-5.132 \\
{[0.244]}\end{array}$ & $\begin{array}{l}-4.674 \\
{[0.312]}\end{array}$ & $\begin{array}{l}-5.622 \\
{[0.364]}\end{array}$ \\
\hline No. of groups & 16 & 16 & 16 & 16 & 16 \\
\hline
\end{tabular}

$*{ }^{* *}$, and ${ }^{* * *}$ denote $10 \%, 5 \%$, and $1 \%$ significance levels, respectively

development-proxied by domestic credit-is an important driver of trade openness in LMICs in Africa. Feeney and Hillman [7] argue that the development of financial markets that alleviate information asymmetries could lead to more trade liberalization and trade flows. Our finding is consistent with Sare et al. [18]. Indeed, the level of domestic financial development promotes trade openness by acting as an insurance mechanism and a source of countries' comparative advantage. More so, if increased international market integration heightens countries' exposure to the vagaries of the world goods market, then the development of domestic financial system as an insurance mechanism might limit barriers to trade.

Despite slight variation in the coefficients of inflation, its effect on trade openness remains positive for both LICs and LMICs, although evidence for the latter shows insignificant coefficients in most of our model specifications. Our evidence is contrary to Romer's [17] hypothesis which asserts a negative relationship between inflation and trade openness. The explanation of this hypothesis is based on time-inconsistency of monetary policy. Columns $1-5$ of Table 2 show a weaker positive nexus between inflation and trade openness as evident by the smaller magnitude of the coefficients of inflation. Specifically, it was revealed that a unit-percentage increase in inflation significantly increases trade openness by $0.001 \%$, suggesting that higher inflation is associated with more openness to trade in LICs. This result is consistent with the findings of Evans [6] and Zakaria [21]. Our evidence is contrary to the conventional view and a plausible explanation of the higher inflation potentially could be the failure of monetary authorities to 
control inflation as economies open up. Also, considering the fact that imports constitute a major share of trade in LICs, the high inflation leading to more openness to trade possibly arises when these economies import inflation from its trading partners via prices of imported goods and services.

Given the coefficients of gross fixed capital formation, we observe significant positive effect of investment on trade openness irrespective of the group of countries. This notwithstanding, the impact of investment on trade openness is higher in LMICs compared to LICs. For instance, a percentage increase in investment significantly increases trade openness by approximately $1.38 \%$ in LMICs relative to $1.27 \%$ for the LICs (see Column 3, Tables 2 and 3). This finding is insensitive to our model specifications and suggests that higher rate of investment accelerates trade openness. This implies that investment cannot be overlooked as one of the crucial determinants of trade openness in both low-income and lower-middle-income countries in Africa, respectively. Unlike the coefficient of domestic savings, which is positive and statistically insignificant for LMICs, there is a negative impact of domestic savings on trade openness for LICs where a unit-percentage increase in domestic savings reduces trade openness by approximately $0.74 \%$. We are tempted to believe that this finding could be as a result of low domestic savings in Africa caused by low income on the back of high inflationary episodes, as highlighted by Osei et al. [16]. Nevertheless, population is not a significant driver of trade openness in both sampled LICs and LMICs in Africa as the coefficients are statistically insignificant.

Turning to the threshold effect of trade openness-economic growth nexus, we found a non-linear relationship between economic growth and trade openness using economic growth as the threshold variable for LICs. From Table 3, coefficient of real GDP per capita and its squared term are both significant, the sign of real GDP per capita is positive and that of real GDP per capita squared is negative implying non-linear relationship between real GDP per capita and trade openness and inverted $U$-shape in particular. The net effect of real GDP per capita evaluated at its mean is positive indicating that a unit-percentage increase in real GDP per capita increases trade openness by approximately $0.07 \%$. Further, we estimate the threshold value associated with the non-linear relationship by taking a partial derivative of openness with respect to economic growth and setting the result to stationary. We find a threshold value of real GDP per capita to be \$1365. This finding clearly indicates non-monotonic nature of the relationship between economic growth and trade openness since the threshold value appears in a meaning range of values of real GDP per capita for LICs. The implication of the non-linear relationship between economic growth and trade openness is that, while real GDP per capita is associated with higher openness, further increase in real GDP per capita beyond the estimated threshold value dampens trade openness. More precisely, economic growth positively influences trade openness up to a threshold per capita of $\$ 1365$. It is, therefore, imperative, to note that economic growth is an important driver of trade openness that needs a crucial attention of policymakers because it can either enhance or harm trade openness. However, our results in Table 3 do not reveal evidence in support of non-linear relationship between economic growth and trade openness for LMICs in Africa given the insignificant effect of the quadratic term.

\section{Conclusion}

Undoubtedly, opening economies to international trade has gained much prominence among policy makers giving the importance of trade openness. However, empirical efforts on the drivers of trade openness have not been rigorous. More so, it is unclear whether economic growth as a driver of trade openness among low-income and lower-middle-income countries differs in terms of its level of effect. In this study, we re-examine the factors influencing countries' international market integration proxied by trade openness in Africa relying on data for both the two income groups while utilizing the generalized method of moments estimation approach. We find that, while trade openness tends to diverge overtime for both the low-income and lower-middle-income countries, our evidence for most part show varying factors influencing openness. More specifically, while economic growth measured by real GDP per capita robustly enhances openness in low-income countries, in the case of lower-middle-income countries, the impact is not robust and largely negative suggesting that higher growth is associated with less openness. We also find that economic growth-openness nexus for the lowerincome countries exhibits non-linearities and inverted U-shaped relationship in particular and an inflection point of $\$ 1365$. Thus, while increases in real GDP per capita enhance openness, beyond this threshold point, any increases in economic growth dampens openness. Hence, as lower-income countries experience higher increases in real GDP per capita overtime, they tend to move towards a lower-middle-income country status with a deleterious implication for its level of openness. This evidence is consistent with the dampening effect of 
economic growth on openness for lower-middle-income countries. Economically, the implication is that countries move towards closed economies on account of higher economic growth. A conjectural elucidation is that, as income increases, economic agents begin to have strong demand for local products and may well be satisfied in autarky. Other determinants of openness are observed. While financial development matters more for lowerincome countries, the impact of finance on openness for lower-middle income is benign. Even for lower-income countries, private (domestic) credit inhibits (promotes) integration with the rest of the World. Domestic savings, inflation and gross fixed capital formation are robust determinants of trade openness for lower-income countries. However, for lower-middle-income countries, only capital formation significantly spurs integration with international markets.

At the policy level, our findings highlight the differential effects on the determinants of openness. More importantly, countries' level of economic growth exerts varying impact of trade openness. Identification of the exact real GDP per capita threshold beyond which growth-openness nexus changes effect is exceedingly crucial in guiding macroeconomic policy around level of openness.

\section{Abbreviations}

CV: coefficient to variation; GDP: gross domestic product; GMM: generalized method of moments; LICs: low-income countries; LMICs: lower-middleincome countries; OECD: Organization for Economic Co-operation and Development; SAARC: South Asian Association for Regional Cooperation; WDI: World Development Indicators.

\section{Acknowledgements}

Not applicable.

\section{Authors' contributions}

DBO reviewed extant studies on trade openness and interpreted the results of the study, and was a major contributor in writing the manuscript. YAS concluded the study and discussed policy implications of our findings. MI analyzed the panel data and discussed the methods of the study. All authors read and approved the final manuscript.

\section{Funding}

No funding was obtained for this study.

\section{Availability of data and materials}

The datasets used and/or analyzed during the current study available from the corresponding author on reasonable request.

\section{Competing interests}

The authors declare that they have no competing interests.

\section{Author details}

${ }^{1}$ Wits Business School, University of the Witwatersrand, 2 St David's Place, Parktown, Johannesburg, South Africa. ${ }^{2}$ Department of Banking and Finance, School of Business and Law, University for Development Studies, Wa, Ghana.
Table 4 List of countries

\begin{tabular}{ll}
\hline Low-income countries (LICs) & $\begin{array}{l}\text { Lower-middle- } \\
\text { income countries } \\
\text { (LMICs) }\end{array}$ \\
\hline 1. Benin & 1. Angola \\
2. Burkina Faso & 2. Cape Verde \\
3. Central African Republic & 3. Cameroon \\
4. Chad & 4. Congo, Republic \\
5. Congo, Dem. Rep. & 5. Cote d'Ivoire \\
6. Ethiopia & 6. Egypt Arab Republic \\
7. Gambia, The & 7. Ghana \\
8. Guinea & 8. Kenya \\
9. Guinea-Bissau & 9. Lesotho \\
10. Liberia & 10. Mauritania \\
11. Malawi & 11. Morocco \\
12. Mali & 12. Nigeria \\
13. Mozambique & 13. Sudan \\
14. Niger & 14. Swaziland \\
15. Rwanda & 15. Tunisia \\
16. Senegal & 16. Zambia \\
17. Sierra Leone & \\
18. Tanzania & \\
19. Togo & \\
20. Uganda & \\
21. Zimbabwe & \\
22. Burundi & \\
\hline
\end{tabular}

Received: 1 Auqust 2019 Accepted: 18 October 2019

Published online: 14 November 2019

\section{References}

1. Alesina A, Wacziarg R (1998) Openness, country size and government. J Public Econ 69(3):305-321

2. Arellano M, Bond S (1991) Some tests of specification for panel data: Monte Carlo evidence and an application to employment equations. Rev Econ Stud 58(2):277-297

3. Arellano M, Bover O (1995) Another look at the instrumental variable estimation of error-components models. J Econom 68(1):29-51

4. Baltagi BH, Demetriades PO, Law SH (2009) Financial development and openness: evidence from panel data. J Dev Econ 89(2):285-296

5. Blundell R, Bond S (1998) Initial conditions and moment restrictions in dynamic panel data models. J Econom 87(1):115-143

6. Evans RW (2007) Is openness inflationary? imperfect competition and monetary market power. Working paper No. 2007 (1), Federal Reserve Bank of Dallas. http://www.dallasfed.org/assets/documents/institute/ wpapers/2007/0001.pdf

7. Feeney J, Hillman AL (2004) Trade liberalization through asset markets. J Int Econ 64(1):151-167

8. Guttmann S, Richards A (2006) Trade openness: an Australian perspective. Aust Econ Pap 45(3):188-203

9. Ibrahim M, Alagidede P (2017) Financial sector development, economic volatility and shocks in sub-Saharan Africa. Phys A 484:66-81

\section{Appendix}

See Table 4. 
10. Ibrahim M, Alagidede P (2018) Effect of financial development on economic growth in sub-Saharan Africa. J Policy Model. https://doi. org/10.1016/j.jpolmod.2018.08.001

11. Jafari Y, Ismail MA, Kouhestani MS (2011) Determinants of trade flows among D8 countries: evidence from the gravity model. J Econ Coop Dev 32(3):21-38

12. Jansen M, Nordås HK (2004) Institutions, trade policy and trade flows. WTO Staff Working Paper ERSD-2004-02. http://dx.doi.org/10.2139/ ssrn.923544

13. Kim DH, Lin SC, Suen YB (2010) Are financial development and trade openness complements or substitutes? South Econ J 76(3):827-845

14. Kletzer K, Bardhan P (1987) Credit markets and patterns of international trade. J Dev Econ 27(1-2):57-70

15. Mbogela CS (2015) Trade openness: an African perspective: examining the determinants of trade openness and bilateral trade flows for the African countries (Doctoral dissertation, University of Hull)

16. Osei DB, Aglobitse PB, Bentum-Ennin I (2017) Relationship between construction expenditure and economic growth in sub-Saharan Africa. Ghana J Econ 5(1):28-55
17. Romer D (1993) Openness and inflation: theory and evidence. Q J Econ 108(4):869-903

18. Sare YA, Aboagye AQ, Mensah L, Bokpin GA (2018) Effect of financial development on international trade in Africa: does measure of finance matter? J Int Trade Econ Dev. https://doi.org/10.1080/09638 199.2018.1474246

19. Tahir M, Hasnu SAF, Ruiz Estrada M (2018) Macroeconomic determinants of trade openness: empirical investigation of SAARC region. J Asia Bus Stud 12(2):151-161

20. Yanikkaya H (2003) Trade openness and economic growth: a cross-country empirical investigation. J Dev Econ 72(1):57-89

21. Zakaria M (2011) Openness and inflation: evidence from time series data. Doğuş Üniversitesi Dergisi 11(2):313-322

\section{Publisher's Note}

Springer Nature remains neutral with regard to jurisdictional claims in published maps and institutional affiliations.

\section{Submit your manuscript to a SpringerOpen ${ }^{\circ}$ journal and benefit from:}

- Convenient online submission

- Rigorous peer review

- Open access: articles freely available online

- High visibility within the field

- Retaining the copyright to your article

Submit your next manuscript at $\gg$ springeropen.com 